\title{
Effect of different drying methods on the physicochemical characteristics of cassava flour ("pupuru")
}

\author{
J.A.V. FAMUREWA*, M. O. OLUWAMUKOMI and J. O. ALABA \\ Department of Food Science and Technology, Federal University of Technology, P. M. B. 704, Akure, Nigeria. \\ *Corresponding author, E-mail: jav_murewa@yahoo.com
}

\begin{abstract}
The effects of smoking, toasting and oven drying methods on the physical and chemical characteristics of "pupuru", a fermented cassava product, were studied. Cassava tubers were manually peeled, washed and steeped in water for four days after which the water was decanted; the soft wet mash was packed into Hessian sack and pressed. One portion was moulded into small-sized $(500 \mathrm{~g})$ ball shape and smoked on wood fire for 72 hours (Traditional method). The second portion was moulded into $500 \mathrm{~g}$ size ball and dried in the hot air oven at $60{ }^{\circ} \mathrm{C}$ for 14 hours. The two products were pulverized and sieved with 60 mesh size into fine pupuru flour. The third wet meal was sifted and toasted on an aluminum pan over fire and then milled into fine toasted pupuru flour. The flours were subjected to physicochemical evaluations. There was reduction in drying time when pupuru was toasted compared to the tradition smoking method. The range of final moisture content achieved was 7.14- $8.40 \%(\mathrm{db})$. Despite the shortness in the drying time, the toasted samples had the lowest moisture content. Irrespective of the drying methods, there were significant differences $(p<0.05)$ in the proximate composition. The crude fibre content was highest in smoked dried with $3.17 \%$ compared to the toasted and oven dried samples with $2.12 \%$ and $2.53 \%$ respectively. The titratable acidity increased by about $78 \%$ from 0.09 to 0.16 with corresponding decrease in $\mathrm{pH}$ from 5.34 to 4.18 . The toasted product had the lowest $\mathrm{pH}$ value of 4.18 while smoked and oven dried had 4.67 and 4.63 respectively. The bulk densities for both loosed and packed $\backslash$ were higher for toasted product with values of 0.54 and $0.62 \mathrm{~g} / \mathrm{ml}$ respectively, while smoked dried had the least value of 0.21 and $0.40 \mathrm{~g} / \mathrm{ml}$. The swelling power was highest in the toasted pupuru with value $0.38 \mathrm{ml} / \mathrm{g}$ and water holding capacity was $259.42 \mathrm{ml} / \mathrm{g}$. The cyanide content of the smoked, oven dried and toasted product were $0.42,0.48$ and $0.47 \mathrm{mg} / 100 \mathrm{~g}$ respectively. The toasting method gave the best sample in terms of drying time, moisture content, physical properties and sensory qualities. It can be concluded that toasting drying method is a better alternative method of producing pupuru.
\end{abstract}

(c) 2013 International Formulae Group. All rights reserved.

Keywords: Cassava, pupuru, physicochemical, sensory, processing.

\section{INTRODUCTION}

Food preservation is as important as food processing itself because methods of food preservation are expected to improve the shelf life of food products. Cassava (Manihot esculenta Crantz) roots are widely used as food in Nigeria. It is one of the most important root crops in most tropical countries and it is estimated that foods processed from cassava roots are staple for over 800 million 
people in the tropics (Nagib et al., 2005). Utilization of cassava roots as food has been in the increase in many countries in the tropic in the past decade (Oduro et al., 2000). Pupuru is a staple starchy food popular in Nigeria, especially in the western part of the country. Pupuru is traditionally prepared by soaking cassava in water for about 3-5 days to become soft. After fermentation, the wet mash is packed into sack and dewatered using a mechanical press. The fibres are handpicked from the mash and the mash are molded into ball or circular shape and placed over fire to smoke dry. The resulting products are spherical-like material with brown appealing appearance. The outer covering is then scraped off with knife and the inner white component is milled and sieved into pupuru flour. This is then reconstituted by stirring in hot water and pounded into a smooth solid food called "pupuru”.

The control and monitoring of conditions in the traditional processing methods are difficult. Another major constraint in the traditional processing of pupuru is the unduly time $(24-72 \mathrm{~h})$, as a result of ineffective heat transfer mechanism using the traditional dryer and probably due to the irregular and large sizes $(1.2-1.8 \mathrm{~kg}$ ) of the ball dried. Therefore, proper drying is not achieved and dried balls have the high moisture content, thus the product is susceptible to mold attack as well as developing some off flavor on storage. Also, prolonged drying may institute some changes that could negatively affect some functional properties of the product (Shittu et al., 2001)

The objective of this work was to provide an alternative method of producing pupuru using oven dried and toasted dried samples of pupuru and to discern the effect of the two drying methods.

\section{MATERIALS AND METHODS Preparation of pupuru}

Cassava tubers were manually peeled, washed and steeped in water for four days until they were softened. The flow chart for samples production is shown in Figure 1. At every 24 hours, the water was decanted and replaced with fresh water in order to reduce the odour. After the fourth day the water was decanted, the soft wet mash was packed into Hessian sack and the water allowed draining off (Odetokun, et al., 1998) by pressing in Federal University of Technology's mechanical press. The fibres were manually removed and the wet meal was divided into three portions. The first part was prepared into pupuru as it is done traditionally. It was moulded into small-sized (500 g) balls shape. The moulded balls were arranged on mat of palm fronds and smoked to dryness using fire wood as a source of smoke for 72 hours. The resulting products were spherical-like materials with brown appearance. The outer covering was scraped off with knife and the inner white component was pulverized and sieved into pupuru flour using Endecolt laboratory Test Sieve with 60 mesh size.

The second portion of the dewatered meal was moulded into $500 \mathrm{~g}$ size ball and dried in the hot air oven (Gallenkamp Model Oven- 160) at a set temperature of $60{ }^{\circ} \mathrm{C}$ for $14 \mathrm{~h}$ (Osundahunsi, 2005). The product was pulverized and sieved with 60 mesh size to have oven dried pupuru flour. The third portion of the wet cassava meal was sifted with a mesh of pore size wider than that of gari to remove shafts. The meal was toasted in wide aluminium pot with constant stirring for some minutes to prevent burning and formation of lumps. It was then milled into fine toasted pupuru flour.

\section{Analyses \\ Chemical characteristics}

Proximate analyses of the pupuru flours were carried out using the standard procedure of Association of Official Analytical Chemist (AOAC, 1990) and carbohydrate by difference. The energy values were calculated by Atwater factor of 4, 9 and 4 for protein, fat and carbohydrate contents respectively. Total titratable acidity (TTA, as $\%$ lactic acid) was determined using the method of Pearson (1976). The $\mathrm{pH}$ was determined on a standardised digital $\mathrm{pH}$ meter. Hydrogen cyanide content of pupuru flour samples was determined using AOAC 
(1990). Gravimetric determination of tannin was done according to the method of Marker and Good Child (1999). Phytate was determined according to the method of Young and Greaves (1990). The oxalate content determination was done according to Day and Underwood (1986). The following mineral contents sodium, potassium, calcium, magnesium, iron, copper, zinc, and lead were determined by wet ashing of pupuru samples as described by Osborn and Voogt (1978).

\section{Physical characteristics}

The swelling power was determined according to Ukpabi and Ndimele (1990). Twenty-five grams of each samples was weighed into 250 measuring cylinder. Cold distilled water $(150 \mathrm{ml})$ was added and cylinder was allowed to stand for four hours before observing the level of swelling. The water absorption capacity was determined by using the method of Sathe et al. (1982). One gram of sample was added to $10 \mathrm{ml}$ of distilled water and stirred with a magnetic stirrer for five minutes. The mixture was centrifuged at $3500 \mathrm{rpm}$ for 30 minutes and the volume of supernatant was noted that is measured by using $10 \mathrm{ml}$ measuring cylinder for each of the sample. The density of water was assumed to be $1 \mathrm{~g} / \mathrm{ml}$. The bulk density of the flour was determined as described by Fashina and Sokhansaj (1993). The values were calculated as the amount in gram that filled up $50 \mathrm{~cm}^{3}$ of a glass cylinder. Brabender amylograph was used on flour-water mixture $10 \%(\mathrm{w} / \mathrm{v})$ to determine the pasting properties. The samples were reconstituted into paste and assessed for colour (appearance), taste, aroma, texture (mouldability) and overall acceptability of the samples by a twenty member semi-trained panellists using ninepoint hedonic scale; $1=$ dislike extremely, $9=$ like extremely ( IFT, 1981; Larmond, 1982).

\section{Statistical analysis}

Means and standard errors of the mean (SEM) of replicate scores were determined and subjected to analysis of variance (ANOVA). Means were separated using the Duncan's New Multiple Range Test (Steel et al., 1997).

\section{RESULTS}

The proximate compositions of pupuru obtained from different drying methods are presented in Table 1. The moisture content of pupuru flour ranged from 7.19 to $8.40 \%$ dry basis. Pupuru dried with smoke have moisture content of $8.40 \%$ while oven dried and toasted have $7.94 \%$ and $7.19 \%$ respectively.

The protein content of oven dried product is $1.34 \%$ while smoke dried and toasted products were $1.91 \%$ and $1.88 \%$ respectively. The crude fibre content was high in smoked dried with $3.17 \%$ compared to the toasted and oven dried sample with $2.12 \%$ and $2.53 \%$ respectively. The smoke dried and oven dried are almost the same 1.05 and $1.06 \%$, while toasted was $0.91 \%$ for ash content. The carbohydrates content was highest in oven dried with $86.36 \%$ compare to other methods. The energy content is 358.03 $\mathrm{kJ}$ in smoked dried while oven dried and toasted has $358.22 \mathrm{~kJ}$ and $359.32 \mathrm{~kJ}$ respectively.

The $\mathrm{pH}$; toasted pupuru has 4.18 , it was much lower than the smoke and oven dried pupuru that has 4.67 and 4.63 respectively compare to the fresh root with value of 5.34. Thus, there was no significant difference between the $\mathrm{pH}$ of the smoked dried and oven dried. Meanwhile there was significant difference ( $p>0.05)$ among the titratable acidity of the three drying methods. The smoke dried and oven dried with value 0.13 and $0.14 \%$ respectively while the toasted has $0.16 \%$. Table 2 shows the water absorption capacity (WAC); there was significant difference $(\mathrm{P} \leq 0.05)$ in the drying methods, the toasted pupuru was $259 \mathrm{ml} / \mathrm{g}$ higher than both smoke and oven dried pupuru with 166 and $187 \mathrm{ml} / \mathrm{g}$ respectively all compared to 115 $\mathrm{ml} / \mathrm{g}$ for fresh roots. The swelling power has $1.09 \mathrm{~g} / \mathrm{ml}$ for smoked dried pupuru while oven dried and toasted pupuru has 0.38 and $3.78 \mathrm{~g} / \mathrm{ml}$ respectively. The oven dried pupuru was significantly lower in swelling power than the smoked dried and toasted pupuru. The loose bulk density for the smoked and oven dried had 0.21 and $0.33 \mathrm{~g} / \mathrm{ml}$ respectively while toasted had the highest value of $0.54 \mathrm{~g} / \mathrm{ml}$. while the packed bulk 
density ranged between 0.40 to $0.62 \mathrm{~g} / \mathrm{ml}$. The anti-nutritional factors determined are shown in Table 3. There was reduction in the cyanide content of pupuru during processing from $14.6 \mathrm{mg} / 100 \mathrm{~g}$ to $0.47 \mathrm{mg} / 100 \mathrm{~g}$ with smoked dried having the lowest cyanide content. Thus there was significant difference in the pupuru obtained from the different methods. There was no significant difference in oxalate content for the smoked dried and the oven dried pupuru the values are $0.36 \mathrm{mg} / \mathrm{g}$ and $0.35 \mathrm{mg} / \mathrm{g}$ respectively. The phytate contents are significant different in the pupuru dried using different methods. The value of phytate ranged from 957.56 to $1071.90 \mathrm{mg} / 100 \mathrm{~g}$.

The mineral analysis is presented in Table 4. The values of the potassium, lead and iron are not significantly different in smoked and oven dried samples. In the calcium content, the toasted pupuru has the highest value of $167.33 \mathrm{mg} / 100 \mathrm{~g}$ while smoked and oven dried pupuru had $160.8 \mathrm{mg} / 100 \mathrm{~g}$ and $144.1 \mathrm{mg} / 100 \mathrm{~g}$ respectively. The magnesium contents are significantly different with toasted having the highest value of 226.85 $\mathrm{mg} / 100 \mathrm{~g}$, the smoked dried had 108.95 $\mathrm{mg} / 100 \mathrm{~g}$ and oven dried had $100.3 \mathrm{mg} / 100 \mathrm{~g}$. Zinc, Lead, Iron and copper were significantly lowest in the oven dried samples $(1.9,0.15$, 0.05 and $0.05 \mathrm{mg} / 100 \mathrm{~g}$ ) respectively; while Lead, Iron and copper were significantly highest in toasted samples $(0.36,0.19$ and $0.19 \mathrm{mg} / 100 \mathrm{~g}$ ) respectively. There was no significant difference in the Zinc content of smoked and toasted samples. Table 5 shows the result of sensory attribute of pupuru with different drying methods. The smoke dried pupuru was scored highest in terms of colour and taste with 6.69 and 6.62 respectively; while the toasted pupuru was scored highest in mouldability, aroma and overall acceptability with $6.63,7.06$ and 6.63 respectively. The oven dried pupuru was scored lowest in almost all the sensory parameters.

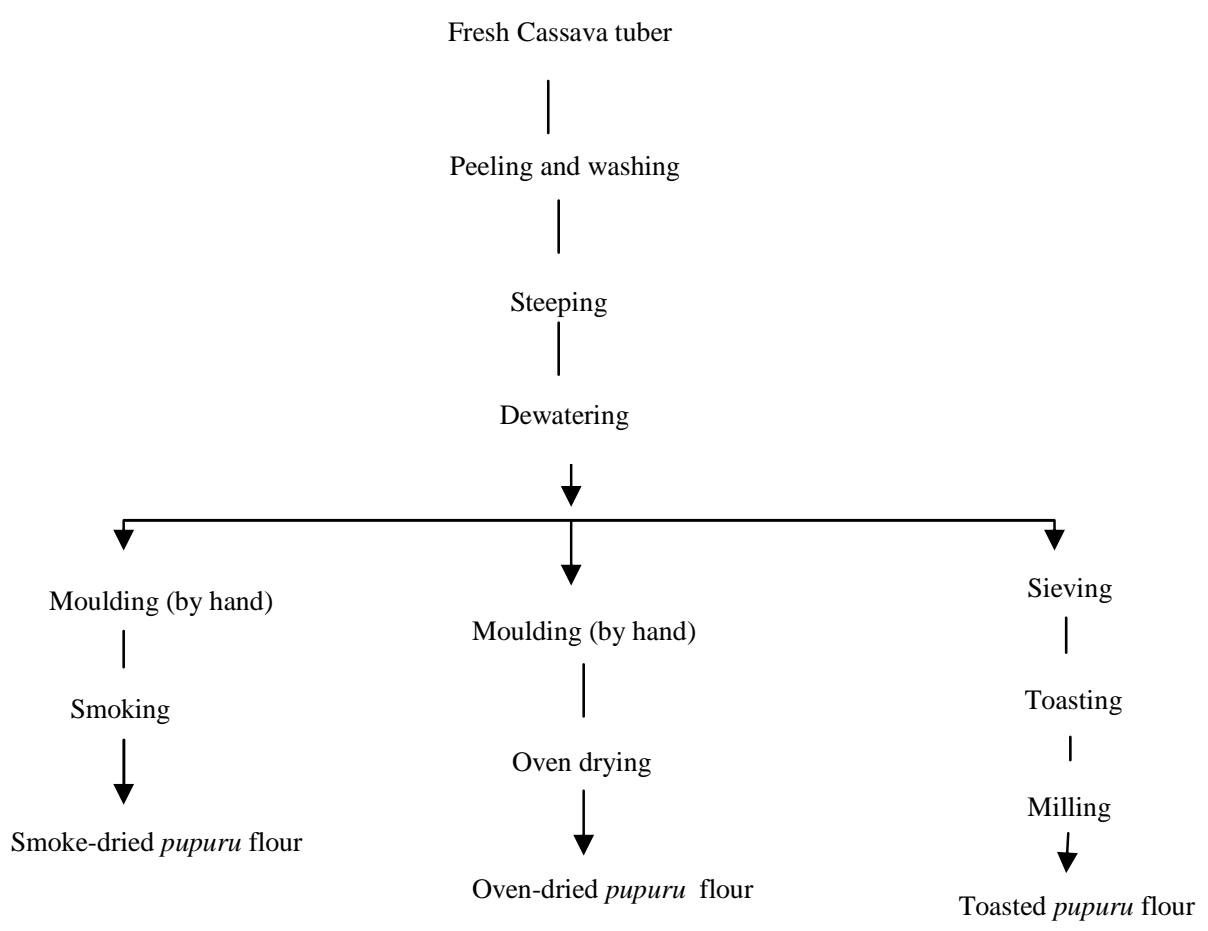

Figure 1: Flow Chart for the production of pupuru flour using different drying methods. 
Table1: Chemical composition of pupuru dried by different methods.

\begin{tabular}{lccc}
\hline Parameter & Smoked- dried & Oven- dried & Toasted \\
\hline Moisture $(\%)$ & $8.40^{\mathrm{a}}$ & $7.94^{\mathrm{b}}$ & $7.19^{\mathrm{c}}$ \\
Ash $(\%)$ & $1.06^{\mathrm{a}}$ & $1.05^{\mathrm{a}}$ & $0.91^{\mathrm{b}}$ \\
Fat $(\%)$ & 0.87 & 0.86 & 0.88 \\
Crude protein $(\%)$ & $1.91^{\mathrm{a}}$ & $1.34^{\mathrm{b}}$ & $1.88^{\mathrm{a}}$ \\
Crude fibre $(\%)$ & $3.17^{\mathrm{a}}$ & $2.53^{\mathrm{b}}$ & $2.12^{\mathrm{c}}$ \\
Carbohydrate $(\%)$ & $85.64^{\mathrm{b}}$ & $86.28^{\mathrm{b}}$ & $85.97^{\mathrm{b}}$ \\
pH & $4.67^{\mathrm{a}}$ & $4.63^{\mathrm{a}}$ & $4.1^{\mathrm{b}}$ \\
Titratable acidity $(\%)$ & $0.13^{\mathrm{c}}$ & $0.14^{\mathrm{b}}$ & $0.16^{\mathrm{a}}$ \\
Energy( kcal) & $358^{\mathrm{b}}$ & $358^{\mathrm{b}}$ & $359^{\mathrm{a}}$ \\
\hline Values are means of triplicate readings; values with different superscript in the row are significantly \\
different (p $\leq 0.05)$.
\end{tabular}

Table 2: Physical properties of pupuru dried by different methods.

\begin{tabular}{lccc}
\hline Parameter & Smoked- dried & Oven- dried & Toasted \\
\hline Water absorption capacity (ml/g) & $165.52^{\mathrm{c}}$ & $187.67^{\mathrm{b}}$ & $259.42^{\mathrm{a}}$ \\
Swelling index (w/v) & $1.09^{\mathrm{b}}$ & $0.38^{\mathrm{c}}$ & $3.78^{\mathrm{a}}$ \\
Bulk density (loosed) g/ml & $0.21^{\mathrm{c}}$ & $0.33^{\mathrm{b}}$ & $0.54^{\mathrm{a}}$ \\
Bulk density (packed) g/ml & $0.40^{\mathrm{b}}$ & $0.42^{\mathrm{b}}$ & $0.62^{\mathrm{a}}$ \\
\hline
\end{tabular}

Values are means of triplicate readings; values with different superscript in the row are significantly different ( $\mathrm{p} \leq 0.05)$.

Table 3: Anti-nutritional factors in pupuru dried using different methods.

\begin{tabular}{lccc}
\hline Parameter & Smoked- dried & Oven- dried & Toasted \\
\hline Cyanide content $(\mathrm{mg} / 100 \mathrm{~g})$ & $0.42^{\mathrm{c}}$ & $0.49^{\mathrm{a}}$ & $0.47^{\mathrm{b}}$ \\
Oxalate $(\mathrm{mg} / \mathrm{g})$ & $0.36^{\mathrm{a}}$ & $0.38^{\mathrm{a}}$ & $0.27^{\mathrm{b}}$ \\
Phytate $(\mathrm{mg} / 100 \mathrm{~g})$ & $1071.90^{\mathrm{b}}$ & $1240.05^{\mathrm{a}}$ & $957.56^{\mathrm{c}}$ \\
Tannin $(\mathrm{mg} / 100 \mathrm{~g})$ & 0.000 & 0.0000 & 0.0000 \\
\hline Values are means of triplicate reading; value with different superscript in the row are significantly different $(\mathrm{p} \leq 0.05)$.
\end{tabular}

Table 4: Mineral content of pupuru flour.

\begin{tabular}{lccc}
\hline Element $(\mathbf{~ m g} / \mathbf{1 0 0 g})$ & Smoked- dried & Oven- dried & Toasted \\
\hline Sodium & $5.45^{\mathrm{a}}$ & $4.95^{\mathrm{b}}$ & $4.45^{\mathrm{c}}$ \\
Calcium & $160.8^{\mathrm{b}}$ & $144.1^{\mathrm{c}}$ & $167.33^{\mathrm{a}}$ \\
Potassium & $259.15^{\mathrm{b}}$ & $260.5^{\mathrm{a}}$ & $160 \mathrm{c}^{\mathrm{a}}$ \\
Magnesium & $108.95^{\mathrm{b}}$ & $100.3^{\mathrm{b}}$ & $226.85^{\mathrm{a}}$ \\
Zinc & $2.8^{\mathrm{a}}$ & $1.9^{\mathrm{c}}$ & $2.7^{\mathrm{b}}$ \\
Iron & $0.18^{\mathrm{b}}$ & $0.15^{\mathrm{b}}$ & $0.36^{\mathrm{a}}$ \\
Lead & $0.1^{\mathrm{b}}$ & $0.05^{\mathrm{c}}$ & $0.19^{\mathrm{a}}$ \\
Copper & $0.7^{\mathrm{b}}$ & $0.05^{\mathrm{c}}$ & $0.19^{\mathrm{a}}$ \\
\hline Values are means of triplicate readings; values with different superscript in the row are significantly different $(\mathrm{p} \leq 0.05)$
\end{tabular}


Table 5: Sensory analysis.

\begin{tabular}{lccc}
\hline Parameter & Smoke - dried & Oven- dried & Toasted \\
\hline Colour & $6.69^{\mathrm{a}}$ & $6.64^{\mathrm{b}}$ & $6.25^{\mathrm{b}}$ \\
Taste & $6.63^{\mathrm{a}}$ & $6.44^{\mathrm{c}}$ & $6.56^{\mathrm{b}}$ \\
Modability & $6.50^{\mathrm{b}}$ & $6.44^{\mathrm{c}}$ & $6.63^{\mathrm{a}}$ \\
Aroma & $6.69^{\mathrm{b}}$ & $6.38^{\mathrm{c}}$ & $7.06^{\mathrm{a}}$ \\
Overall acceptance & $6.56^{\mathrm{b}}$ & $6.44^{\mathrm{b}}$ & $6.63^{\mathrm{a}}$ \\
\hline
\end{tabular}

Values are means of triplicate reading with different superscript in the row are significantly different $(\mathrm{p}<0.05)$.

\section{DISCUSSION}

The rate of drying was influenced by the drying method. Drying time for oven drying was $14 \mathrm{hrs}$, the toasted $4 \mathrm{hrs}$ and $24 \mathrm{hrs}$ for the traditional smoking method. Osundahunsi (2005) reported that the moisture content as 12.21 and $12.90 \%$ for both smoked and oven dried while Odetokun et al. (1998) reported 9.86 and $10.20 \%$ for traditional prepared pupuru. Onayemi and Oluwamukomi (1987) reported that optimum stability of cassava and yam lies between $6.5 \%$ and $8.0 \%$. The toasted sample has the lowest moisture content; this may be attributed to high heat process during toasting. . This is in agreement with Aboua (1995) who reported that moist cassava products have short shelf-life. The traditional smoke drying usually takes a long time (24-72 hr) which is the major constraint in the traditional processing of pupuru and probably due to the irregular and large sizes of the balls to be dried. As a result, proper drying is not achieved and dried balls have high moisture content, thus the product is susceptible to mould attack as well as developing some off flavour. However, such problem was eliminated by toasting method The protein content is low; however, cassava as a stable food has the problem of protein deficiency but they are indispensable food in many homes in Nigeria. The crude fibre was high in smoke dried due to the fact that it was not milled unlike toasted that has the lowest value of crude fibre because it was milled. The samples are within the nutritionally maximum level of 3.0\% as reported by Ibe (1981) for processed gari. There was no significant difference $(p>0.05)$ in fat content of the samples of the three drying methods; the oven dried has $0.86 \%$, smoked dried has $0.87 \%$ and toasted has $0.88 \%$. There was significant difference $(\mathrm{p}<0.05)$ among the titratable acidity of the three drying methods. The fresh roots was $0.09 \%$ while there was no significant difference between the smoke dried and oven dried with value 0.13 and $0.14 \%$ respectively, the toasted has $0.16 \%$. The titratable acidity increased with corresponding decrease in $\mathrm{pH}$ revealing increase in acidity, which could be as a result of acid produced during fermentation. Similar result has been reported by Osundahunsi (2005). The toasted pupuru has the highest value for packed bulk density while there was no difference between the smoked dried pupuru and oven dried pupuru. The differences could be as a result of further processes involved in toasted pupuru. These values increased with the decrease in moisture contents of the flour. Faborode et al. (1992) and Fashina and Sokhansaj (1993) similarly observed increase in the bulk density of the particulate foods produced from maize, cassava and alfalfa as their moisture contents increased. The bulk density of solid food material determines the ease of packing during handling, processing and storage. The smoke dried sample had the lowest hydrocyanic acid (HCN) while the oven dries had the highest. This reduction in smoke dried product must have been due to the prolonged exposure to heat leading to volatilization of more $\mathrm{HCN}$. These values were lower than the 
recommended standard value of $2.0 \mathrm{mg} / 100 \mathrm{~g}$ (Ingram, 1975; NIS 181, 2004). Pupuru made from any of the methods used in this study would be safe for consumption since values recorded $(0.42-0.49 \mathrm{mg} / 100 \mathrm{~g})$ were far below these reported values. The reduction in cyanide content could be attributed to synergistic effect of loss by hydrolysis into the steeping water during fermentation (Opadokun and Ikeorah, 1984) and evaporation during drying (Sanni et al., 1994 and Okpokiri, 1995). The wood used for smoking did not deposit high phenol content in the product which is confirmed by absent of tannin.

In terms of sensory qualities, the panelist most preferred the colour and the taste of the smoked sample. This might have been due to the fact the back was scraped off before milling and the smoking did not have any deleterious effect on the colour and the taste. During smoking, there is deposition of organic components like phenols, which impacts flavor and antimicrobial effect on the product. This could have enhanced acceptability in term of colour and taste, more so, panelists are more familiar with the smoke dried product. They however most preferred the toasted sample in terms of mouldability, aroma and overall acceptability. the aroma. The aroma of smoked dried was similar to the toasted sample but significantly different from oven dried.

\section{Conclusion}

From this study, it could be concluded that the toasting method produced the best pupuru in terms of lower moisture content, physical properties and more acceptable sensory qualities. Toasting method has shown to be a better alternative to the traditional smoking method of producing pupuru.

\section{REFERENCES}

AOAC (Association of Official Analytical Chemist). 1990. Approved Official Methods of Analysis (17 ${ }^{\text {th }}$ edn, vol. 1).
AOAC: Horowitz, Maryland Ch.; 45, 112-120.

Day RA, Underwood AS. 1986. Qualitative Analysis $\quad\left(5^{\text {th }}\right.$ edn $)$ Prentice Hall Publication; 701

Faborode MO, Gbadegesin AB, Olotu OM, Eboreime OK. 1992. Steeping and drying characteristics of maize and cassava and their products. Nigerian Food Journal, 10: 51-57.

Fashina OO, Sokhansaj S. 1993. Effect of moisture contents on bulk handling properties of alfalfa pellets. Canadian Agric. Eng., 35(4): 269 - 273.

IFT. 1981. Sensory evaluation guide for testing food and beverage products by the sensory Evaluation division of the Institute of Food Technologists. Food Technol., 35(11): 50-59.

Ingram JS. 1975. Standard Specifications and Quality Requirements for Processed Cassava Products. Tropical Product Institute: London; 11-12.

Larmond E. 1977. Methods of sensory testing. In Laboratory Methods for Sensory Evaluation of Foods. Canadian Dept of Agric.: Ottawa.

Marker AO, Good Child AV. 1999. Quantification of Tannins a Laboratory Manual. International Centre for Agricultural Research in Dry Areas (ICARDA): Aleppo, Syria; 25pp.

Nagib N, Carla SV, Humberto L, Carla AS, Osmindo RP. 2005. Potentiality of cassava cultival as a source of carotenoids. Journal of Food, Agriculture and Environment, 3/4: 33 -35.

NIS 181. 2004. Standard for "gari". In Standard for Cassava Products and Guidelines for Export, Sanni et al., (eds). IITA: Ibadan, Nigeria.

Odetokun SM, Aiyesanmi AF, Esuoso KO. 1998. Enhancement of the nutritive value of pupuru, a fermented cassava product. Riv. Ital. Sostanze Grasse, 75: 155- 158.

Oduro I, Ellis W, Dziedzoave N, Nimako K. 2000. Quality of gari from selected 
processing zone in Ghana. Food Controls 11: 297-303.

Okpokiri AO, Ijeoma BC, Alozie, Ejiofor MAN. 1995. Production of improved cassava fufu. Nigeria Food Journal, 3: $145-148$.

Onayemi O, Oluwamukomi MO. 1987. Moisture equilibria of some dehydrated cassava and yam products. Journal of Food Process Engineering, 9: 191 -200.

Opadokun JS, Ikeorah JN. 1984. Survey of hydrogen cyanide content of cassava products on sale in Ibadan markets. Rep. Nigerian stored Prod. Res. Technical Report $\mathrm{N}^{\circ} 7,57-61$.

Osborne DR. Voogt P. 1978. Calculation of calorific values. In The Analysis of Nutrients in Foods. London Academic Press: London; 239.

Osundahunsi OF. 2005. Effect of drying methods on composition, sensory evaluation and rheological value of pupuru (fermented cassava product). Journal of Food Technology, 3(3): 353355.

Pearson. 1976. Chemical Analysis of Food ( $7^{\text {th }}$ edn), Church Chill Living - Stone: London; $204-237$.
Sanni M, Sobamiwa O, Eyinla M, Rosling H. 1994. Safety aspects of processing cassava to gari in Nigeria. Acta Hort., 372: $227-231$

Sanni LO, Akingbala JO, Oguntunde AO, Bainbridge ZA, Graffham AJ, Westby A. 1998. Processing of fufu from cassava in Nigeria: Problems and prospects for development. Science, Technology and Development, 16(1): 58-71.

Sathe SK, Desphande SS, Saunkhe DK. 1982. Functional properties of Lupin seed (Lupinus mutabilis) proteins and protein concentration. Journal of Food Science, 47: 491-497.

Shittu TA, Lasekan OO, Sanni LO, Oladosu MO. 2001. The effect of drying methods on the functional and sensory characteristics of pupuru- a fermented cassava product. ASSET Series A, 1(2): 916

Ukpabi UJ, Ndimele C. 1990. Evaluation of the quality of gari produced in Imo state. Nigeria Food Journal, 8: 106 -109.

Young SM, Greaves JS. 1990. Influence of variety and treatment on phytic acid content of wheat. Food Research, 5: 103105 . 